\title{
Cristologia e diálogo entre as religiões na busca da paz em Claude Geffré
}

\author{
Christology and dialogue between religions in \\ search of peace in Claude Geffré \\ ÉRICO JOÃO HAMMES \\ TIAGO DE FRAGA GOMES ${ }^{b}$
}

\section{Resumo}

A presente pesquisa visa abordar o conceito cristológico, proposto por Claude Geffré, de economia do Verbo encarnado, como sacramento de uma economia mais vasta, em sua relevância para fundamentar o diálogo entre as diferentes tradições religiosas em busca da paz. Pretende-se refletir sobre a dinâmica da economia da revelação diante do pluralismo religioso hodierno; propor o paradoxo cristológico da irrupção de Deus na particularidade histórica de Jesus de Nazaré como espaço dialógico de aprofundamento do significado da pluralidade das religiões como manifestação da riqueza multiforme do mistério divino; superar a ideia triunfalista cristã sobre as outras religiões pela reinterpretação da unicidade do Cristianismo em meio a uma pluralidade de narrativas teológicas; alertar que não haverá paz civil, nem paz mundial, sem paz entre as religiões, possível apenas através do diálogo. Almeja-se conscientizar sobre a possibilidade de uma resolução criativa e não violenta dos conflitos entre as diversas tradições religiosas; propor uma abertura dialógica que promova uma igualdade de dignidade na diferença de identidades na superação de toda pretensão monopolizadora da verdade entre as

\footnotetext{
a Pontifícia Universidade do Rio Grande do Sul (PUCRS), Porto Alegre, RS, Brasil. Doutor em Teologia, e-mail: ehammes@pucrs.br

b Pontifícia Universidade do Rio Grande do Sul (PUCRS), Porto Alegre, RS, Brasil. Mestre em Teologia, email: tiago_mail@yahoo.com.br
} 
religiões; consolidar uma educação e uma espiritualidade cristãs para a paz e não violência.

Palavras-chave: Cristologia. Revelação. Diálogo. Religiões. Paz. Geffré.

\section{Abstract}

The present research aims to address Claude Geffre's Christological concept of the Incarnate Word economy as a sacrament of the wider economy, its relevance to support the dialogue between the different religious traditions in search of peace. It is intended to reflect on the dynamics of the economy of the revelation before today's religious pluralism; propose the Christological paradox of the irruption of God in the historical particularity of Jesus of Nazareth as a dialogic space of deepening the meaning of the plurality of religions as a manifestation of the richness and variety of the divine mystery; overcoming the Christian triumphalist idea on other religions by the reinterpretation of the uniqueness of Christianity among a plurality of theological narratives; warn that there will be no civil peace or world peace without peace among religions, possible only through dialogue. It also aims to raise awareness of the possibility of a creative and non-violent resolution of conflicts between different religious traditions; propose a dialogical opening to promote equal dignity in the identities of difference in overcoming all monopolistic claim of truth among religions; consolidate an education and a Christian spirituality for peace and nonviolence.

Keywords: Christology. Revelation. Dialogue. Religions. Peace. Geffré.

\section{Introdução}

A vinculação entre Cristianismo e paz nem interna e muito menos externamente é uma unanimidade. Seja no passado, seja no presente houve e há sempre leituras justificadoras da guerra e da violência no Cristianismo. E do ponto de vista externo, ataca-se a condição monoteísta e a pretensão à verdade como sendo incompatíveis com uma fundamentação e engajamento em favor da paz e não violência. De outro lado, contudo, o diálogo interreligioso e a paz também são parte histórica do encontro entre o Cristianismo e as demais religiões. O Cristianismo primitivo procurava harmonizar suas concepções de fé com as tradições judaicas e romanas a fim de evitar as áreas de atrito entre as diferentes concepções. Essa compreensão mudou quando o Cristianismo se tornou hegemônico ao final do Império Romano. Tendo aceitado inicialmente, com as restrições de Santo Agostinho, a ideia da guerra 
justa, estendeu de forma abusiva o recurso da violência contra as demais religiões. No entanto, na passagem da Idade Média à Modernidade, nomes como Nicolau de Cusa e Erasmo de Roterdã propuseram a via pacífica na relação com outras tradições de fé. No ambiente colonialista, podem citar-se Bartolomé de las Casas e Antonio de Montesinos, que buscaram convencer as metrópoles sobre o imperativo do respeito às religiões nativas contra a prática da subjugação e destruição. Em tempos recentes, várias iniciativas buscam oferecer uma alternativa ao uso violento de motivações religiosas na forma de diálogo inter-religioso. Surge, assim, no caso da Igreja Católica a partir do Concílio Vaticano II, uma Teologia do pluralismo e diálogo inter-religioso com diferentes caminhos de solução. Algumas das principais questões a serem pesquisadas são as relações entre identidade e diálogo, singularidade e pluralidade, autoafirmação e convivência pacífica, pretensão à verdade própria e reconhecimento recíproco.

Busca-se, então, pensar, a partir da condição atual de uma época planetária e da consciência de habitar em uma casa comum, de que maneira as religiões podem ajudar na superação das divergências raciais, culturais e religiosas entre as pessoas e na preservação do ambiente?

Na encíclica Laudato Si' sobre o cuidado da casa comum, o Papa Francisco chama a atenção para o fato de que "a maior parte dos habitantes do planeta declara-se crente, e isto deveria levar as religiões a estabelecer diálogo entre si, visando o cuidado da natureza, a defesa dos pobres, a construção de uma trama de respeito e fraternidade" (LS 201). No que tange às religiões, o que une deveria ser mais importante do que aquilo que separa, pois nenhuma religião é absolutamente perfeita. Apesar de buscarem o absoluto, todas as religiões inserem-se no interior do estatuto da relatividade histórica. A grande questão segundo Geffré é que "não haverá paz civil, nem paz mundial, sem paz entre as religiões” (GEFFRÉ, 2013, p. 15). As religiões precisam compreender a sua responsabilidade histórica a serviço da vida e da convivência humana ${ }^{1}$. As atitudes antiéticas realizadas em nome da religião são

\footnotetext{
${ }^{1}$ Segundo Küng, não haverá sobrevivência do mundo sem a paz entre as religiões. "Não haverá paz entre as nações, se não existir paz entre as religiões. Não haverá paz entre as religiões, se não existir diálogo entre as religiões. Não haverá diálogo entre as religiões, se não existirem padrões éticos globais" (KÜNG, 2004, p. 280). Para Küng, as religiões, na medida em que fomentam um
} 
revoltantes para a consciência humana universal. Nesse sentido, surge o questionamento: a partir do próprio centro da fé cristã, como se pode fundamentar de forma relevante o diálogo entre as religiões em prol de uma cultura de paz e não violência?

O presente artigo pretende refletir a contribuição do diálogo inter-religioso para a paz, tomando como referencial a obra de Claude Geffré, nascido em 1929 e falecido em fevereiro de 2017. Teólogo reconhecido por sua contribuição no campo da hermenêutica e da Teologia das Religiões, possui várias obras publicadas no Brasil e mereceu diversas pesquisas. Para uma primeira aproximação pode buscar-se o artigo de Faustino Teixeira (1998). Em sua apresentação destaca o ponto de partida do teólogo francês, a Teologia Hermenêutica, donde brota a reflexão teológica do pluralismo religioso, enquanto um novo horizonte. Exige um modelo diferente para pensar a relação do Cristianismo com as outras religiões, já que nem o inclusivismo (inclusão das outras religiões no Cristianismo) nem o pluralismo radical (igualdade de todas as religiões, independentemente de sua relação ao evento Cristo) podem dar conta adequada da realidade religiosa plural. Teixeira identifica o traço distintivo de Geffré na proposta de um cristocentrismo aberto "aceitando a interlocução fecundante do pluralismo" (TEIXEIRA, 1998, p. 50) e da dimensão quenótica do Cristianismo, na medida em que na cruz se concretiza a universalidade aberta e inesgotável da encarnação do Verbo (p. 63-65). Como parte dessa atitude respeitosa e dialogal a Teologia de Geffré - constata acertadamente o Prof. Faustino Teixeira (1998, p. 76s) - mira o papel colaborativo das religiões na construção da paz.

Este estudo tem a intenção de elaborar o tema da economia do Verbo encarnado como fundamento cristológico para o diálogo entre as religiões, e deste modo relacionar a importância de uma hermenêutica da paz para as religiões. Não se trata, portanto, de estudar especificamente a Teologia do Pluralismo Religioso de Geffré, já sistematizada por Teixeira (1998) e outros. A partir do fato atual de um mundo experienciado em seu pluralismo religioso (1), destaca-se (2) a importância da hermenêutica para uma convivência 
religiosa pacífica e o papel formativo das religiões para a paz e a superação da violência nas sociedades atuais, para num terceiro passo (3) reler a Cristologia em sua relação potencial com a construção e formação para a paz e a superação da violência.

\section{O pluralismo religioso como questão insuperável}

O pluralismo religioso tornou-se uma questão insuperável devido à "relatividade histórica das religiões" (GEFFRÉ, 2013, p. 63), inclusive do Cristianismo, apesar de estarem em busca do Absoluto. Impõe-se a problemática a respeito do "significado da pluralidade das religiões no único desígnio de Deus" (GEFFRÉ, 2013, p. 64): uma questão que reflete a condição geral do pluralismo cultural obrigando "a reinterpretar algumas verdades fundamentais do Cristianismo" (GEFFRÉ, 2004, p. 131). Essa experiência traz consigo um momento de incerteza social generalizada (BAUMAN, 2007, p. 89), e que paradoxalmente concilia ao mesmo tempo secularização, ateísmo, indiferença religiosa, retorno ao religioso e concepções religiosas que divergem da Escritura (GEFFRÉ, 2004, p. 134).

Para o Cristianismo, seguir os passos de Jesus Cristo nas condições mudadas da sociedade atual por um lado remete-se aos seus inícios, a partir do Judaísmo, mas logo também no mundo greco-romano. Por outro lado, é preciso repensá-lo a se repensar criativamente, pois ser cristão não é simplesmente proceder a uma imitação mecânica do que Cristo fez no passado, mas é preciso crer e interpretar, ou seja, atualizar o conteúdo da fé, fazer um aggiornamento, para então entender as implicações da fé diante dos questionamentos hodiernos. Em palavras de Geffré (1989, p. 270), “o cristão não está, pois, condenado ao ideal impossível de reproduzir o que Cristo fez. Ao contrário, ele está entregue à sua consciência, iluminada pelo Espírito, para inventar o que Cristo faria hoje". E o que Cristo faria hoje diante de um mundo que se tornou tão diverso e ao mesmo tempo tão carente de diálogo e de compreensão entre as pessoas das diversas tradições religiosas?

Enquanto para várias outras confissões cristãs e outras religiões o pluralismo é assimilado com relativa facilidade, no caso da Igreja Católica, e setores do Cristianismo, pela pretensão à verdade, houve e há dificuldades 
para renunciarem à imposição sobre os demais. Foi a partir do diálogo ecumênico, assumido pela Igreja Católica no Concílio Vaticano II que a postura católica absolutista, hegemônica e eclesiocêntrica foi sendo oficialmente revista. Foi ocasião de alguns deslocamentos eclesiológicos fundamentais (LIBANIO, 2005, p. 145-146), os quais foram importantes para que o Magistério eclesiástico pudesse emitir um julgamento positivo sobre as outras confissões religiosas, assumindo uma postura dialógica. Nesse sentido, a Teologia é chamada "a reinterpretar a unicidade do Cristianismo" (GEFFRÉ, 2004, p. 134), superando o triunfalismo ideológico em relação às outras religiões, para expressar de forma criativa e não violenta a sua identidade peculiar em meio a uma pluralidade de narrativas teológicas, as quais possuem um alcance hermenêutico relevante na leitura dos arquétipos antropológicos, culturais e religiosos, que estão no substrato dos estados de consciência hodiernos.

É possível desnudar o Cristianismo de certa pretensão absolutista sem enveredar para um relativismo doutrinal ou para um indiferentismo prático. Da mesma forma, é possível manter um engajamento forte em relação à mensagem cristã, sem por isso, alimentar uma postura imperialista ou exclusivista na relação com outras tradições religiosas. A posição que Geffré defende é a de manter a unicidade e a singularidade da mediação de Cristo sem excluir nem pretender assimilar o valor salutar das outras religiões. Impõe-se, assim, a dimensão dialógica da religião cristã.

Para uma compreensão melhor da dinâmica da revelação, Geffré usa as narrativas bíblicas de Babel e Pentecostes. Babel é o símbolo da ambição idolátrica de uma humanidade monolítica que quer substituir o único Deus. Babel representa o desejo de poder e de uniformidade. Já Pentecostes representa o encontro na pluralidade. Em Pentecostes, a pluralidade das línguas e das culturas é sinal da ação do Espírito Santo. "Com a efusão do Espírito do Ressuscitado, em Pentecostes, é permitido pensar que a pluralidade das línguas e das culturas é necessária para traduzir a riqueza multiforme do Mistério de Deus" (GEFFRÉ, 2013, p. 67). Deus cria o ser humano plural como homem e mulher, e o chama a viver em comunidade, em relação. Deus abençoa o múltiplo. Nesse sentido, é possível pensar em uma pluralidade de economias da salvação em uma "história da salvação diferenciada" (GEFFRÉ, 2013, p. 68), que prescinde de uma conceituação cronológica, ousando 
preconizar uma história ontológica que tem em Cristo o arquétipo primordial da humanidade.

Para Geffré, “toda forma religiosa que favorece a descentralização do homem em prol de um maior do que si mesmo e em prol do outro" (GEFFRÉ, 2013, p. 78), seja ela orante, axiológica ou contemplativa, é misteriosamente sustentada pelo Espírito Santo. Por isso, "é na prática de suas próprias tradições religiosas que os membros das outras religiões respondem positivamente à oferta de salvação de Deus" (GEFFRÉ, 2013, p. 77). A partir da consciência das ambiguidades e contradições existentes em muitas religiões, é necessário "praticar um discernimento crítico" (GEFFRÉ, 2013, p. 77) que ajude a avaliar no interior de cada religião quais dos seus elementos constitutivos "favorecem a abertura para o Absoluto e a prática da justiça no sentido do Reino de Deus que nos foi revelado em Jesus Cristo" (GEFFRÉ, 2013, p. 77). Sendo assim, entende-se que as religiões participam de uma vasta economia da salvação, e que as pessoas podem ser salvas na e através de sua pertença a determinada tradição religiosa.

Os homens e as mulheres de boa vontade e de coração sincero contribuem a seu modo para o advento do Reinado de Deus. Cada figura religiosa contém algo de irredutível que não pode ser integrado no Cristianismo histórico. Além disso, a consciência da ausência original que dá fundamento à fé cristã "é a condição de uma aproximação com o outro, com o estrangeiro, com o diferente" (GEFFRÉ, 2013, p. 84). Segundo Geffré, à luz de uma Teologia da cruz, é possível compreender o Cristianismo não como uma totalidade fechada, mas como relação dialógica, e mesmo como uma falta. "É o túmulo vazio, a ausência do fundador que foi o advento do corpo da comunidade cristã primitiva e do corpo das Escrituras" (GEFFRÉ, 2013, p. 8384). A essa condição nosso autor chama de dimensão quenótica do Cristianismo e sugere ser esse o fundamento cristológico para o caráter não imperialista e relacional do Cristianismo frente às outras religiões.

A singularidade cristã no concerto das religiões do mundo não está no fato de ser exclusiva ou inclusiva de outras experiências, mas em ser "sinal daquilo que lhe falta" (GEFFRÉ, 2013, p. 84), como relação, que não fragmenta ou divide, mas que une, mantendo a diversidade na alteridade, no respeito e na reverência mútuas. O Cristianismo histórico enquanto religião não absoluta 
é testemunha da revelação de forma a não esgotar a riqueza presente nas outras tradições religiosas. Cristo mesmo não se esgota no Cristianismo. Pode fazer-se recurso da economia do Verbo encarnado, como paradoxo do Logos feito carne, para entender a dinâmica da revelação universal de Deus na história multicultural e plurirreligiosa da humanidade. O paradoxo do Logos feito carne "não decorre de uma contradição lógica, mas do fato de um acontecimento que transcende todas as expectativas e possibilidades humanas" (GEFFRÉ, 2013, p. 92). O paradoxo diz respeito à união do Logos eterno de Deus com a carne histórica e temporal humana na pessoa de Cristo, concebido como absolutamente concreto e absolutamente universal.

Na medida em que "o Verbo que se fez carne" (Jo 1,14) em Jesus de Nazaré "é o sacramento de uma economia mais vasta que coincide com a história religiosa da humanidade" (GEFFRÉ, 2013, p. 54). Segundo Geffré, aprofundar o significado do mistério da encarnação, no qual Deus, para se revelar, entra na história e assume as limitações humanas (cf. DUPUIS, 1999, p. 346-347; TORRES QUEIRUGA, 1997, p. 54-55), pode ajudar a fundamentar o diálogo inter-religioso, abrindo espaço para a compreensão de que "as múltiplas expressões do fenômeno religioso concorrem, à sua maneira, para uma melhor manifestação da plenitude inesgotável do mistério de Deus" (GEFFRÉ, 2013, p. 55). Tal concepção alimenta uma postura pacífica e não violenta entre as religiões, contrária a uma impostação belicista e de conquista, muitas vezes fomentada na história do Cristianismo. Verdades diferentes não são necessariamente inimigas ou contraditórias, mas podem ser companheiras ou complementares na resposta aos inúmeros questionamentos religiosos da humanidade (TEIXEIRA, 1998, p. 59-60). Pois, "é o próprio paradoxo da encarnação, a saber, a presença do Absoluto numa particularidade histórica, que nos convida a não qualificar de absoluto o Cristianismo como uma religião exclusiva de todas as outras" (GEFFRÉ, 2013, p. 131).

Isso leva a compreender que o mistério divino ultrapassa os conceitos humanos limitados e circunscritos, bem como as experiências particulares, e faz ir ao encontro do outro, no anseio de plenitude, na procura de uma verdade mais ampla. É possível buscar no próprio centro da fé cristã os motivos que levam à busca da Verdade através do encontro com a verdade do outro. Para Geffré, "nenhuma manifestação histórica de Deus, mesmo o acontecimento 
Jesus de Nazaré, pode ser tida como absoluta. Isso seria cair no docetismo e não levar a sério a humanidade de Jesus" (GEFFRÉ, 2013, p. 74), pois “o Absoluto corresponde somente a Deus; o que cabe ao homem é a tarefa inacabável de ir assimilando-o” (TORRES QUEIRUGA, 1997, p. 22). Nesse sentido, "é vocação dos cristãos anunciarem a todas as pessoas que a salvação de Deus veio em Jesus Cristo, respeitando os caminhos misteriosos de Deus no coração de cada uma" (GEFFRÉ, 2004, p. 180), pois Deus quer se revelar e salvar a todos.

É claro que, na medida em que todo encontro provoca a aceitar o estatuto da historicidade humana e a relativizar os esquemas pessoais de compreensão, faz avançar na inteligência da própria identidade a partir do confronto com a verdade do outro que desestabiliza e provoca a sair da zona de conforto e ingressar em uma peregrinação em busca da verdade. Como religião da encarnação, o Cristianismo é a religião da historicidade, da relatividade, pois apenas o Reinado de Deus é absoluto. "É o caráter original do Cristianismo como religião da encarnação que funda sua natureza dialogal” (GEFFRÉ, 2013, p. 38).

Essa manifestação concreta do mistério absoluto em via de aproximação quenótica na cruz de Jesus "é o símbolo de uma universalidade sempre ligada ao sacrifício de uma particularidade” (GEFFRÉ, 2013, p. 40). Jesus morre em sua particularidade para ressuscitar como o Cristo universal. A partir dessa dialética é possível repensar uma abertura ao outro, articulando a universalidade da mensagem cristã com a pluralidade das tradições religiosas e culturais, e a perceber que a pretensão à universalidade do Cristianismo não se verifica historicamente.

\section{A hermenêutica da linguagem religiosa}

Ao dialogarem entre si, a respeito de sua maneira de crer e dos conteúdos de sua convicção religiosa, os representantes das religiões possibilitam o ensaio de uma habilidade essencial para a construção da paz: a relação não violenta. Transformam uma relação de violência simbólica em relação criativa e pacífica. Segundo Teixeira, "diante de uma realidade caracterizada pelo pluralismo religioso, não há mais condições de uma 
perspectiva de entrincheiramento, de fixação num único itinerário, sem se dar conta da singularidade e da riqueza de outros caminhos" (TEIXEIRA, 1995, p. 188). A abertura à relação com o outro, reconhecendo-o em sua alteridade $e$ diferença irredutíveis, precisa ser vista não como uma ameaça, mas como uma beleza que se manifesta na diversidade, cuja pluralidade de singularidades edifica a todos. "Identidade e alteridade não se excluem; antes, se conjugam" (TEIXEIRA, 1995, p. 189). O encontro com o outro é condição de possibilidade para a afirmação saudável da própria identidade.

Para edificar a paz entre as religiões, é preciso começar pela linguagem, ou seja, pela forma como se pretende expressar a verdade sobre Deus. Segundo Geffré, a Teologia entendida em um sentido hermenêutico designa uma maneira peculiar de fazer Teologia (GEFFRÉ, 2004, p. 29-30; GOMES, 2015, p. 12; MAGALHÃES, 2009, p. 6). De acordo com Geffré, outrora a razão teológica foi identificada com a razão metafísica especulativa (GEFFRÉ, 2004, p. 31) que partia de princípios necessários axiomáticos (GEFFRÉ, 2004, p. 32). Atualmente, a Teologia assume como método o compreender histórico-crítico, passando a se entender não mais como um discurso sobre Deus, mas a respeito da linguagem humana sobre Deus (GOMES, 2015, p. 12), pois Deus excede os limites da racionalidade (GEFFRÉ, 2004, p. 32). Cada vez mais a ciência teológica se dá conta de que não existe conhecimento imediato da realidade fora da linguagem (GEFFRÉ, 2004, p. 36), e a linguagem é inevitavelmente uma interpretação (GEFFRÉ, 2004, p. 33).

A questão hermenêutica é uma problemática filosófica e teológica de fundamental importância, pois remonta aos pressupostos epistemológicos de toda investigação e compreensão da realidade, mais ainda da Teologia. A palavra "hermenêutica" provém do verbo grego hermeneuein, e significa declarar, anunciar, esclarecer, traduzir (CORETH, 1973, p. 1; GIBELLINI, 2002, p. 57-58; LEXICON, 2003, p. 334). Refere-se à atividade interpretativa ou esclarecedora diante de um enunciado obscuro ou de difícil compreensão, cujo sentido não é imediato, justamente porque toda tradução de sentido "consiste na transposição de um complexo significativo para outro horizonte de compreensão linguística" (CORETH, 1973, p. 2). No fundo, não há certezas filológicas ou gramatológicas absolutas, mas apenas probabilidades de tradução e transposição de sentido, cujo intuito é a comunicação de uma 
mensagem pela aproximação de horizontes de compreensão, sem trair seus aspectos mais próprios e essenciais intencionados.

A investigação hermenêutica acontece primeiramente no âmbito teológico como arte da compreensão ou doutrina da boa interpretação, correta e objetiva, da Escritura. Logo em seguida, surgiu também a preocupação com a forma correta de interpretar os textos profanos, em várias áreas do conhecimento. A hermenêutica bíblica tem afinidade com a hermenêutica histórico-filológica no que diz respeito aos métodos empregados na interpretação dos textos escritos, e também tem certo parentesco com a hermenêutica jurídica, pois ambas tratam de textos pretensamente válidos e normativos. O problema propriamente bíblico aborda a Palavra de Deus "transmitida numa palavra humana e histórica” (CORETH, 1973, p. 3), segundo modos e maneiras de pensar situados e contextualizados historicamente. Nesse sentido, "cumpre indagar qual seu sentido mais profundo e mais próprio, a saber, a palavra da revelação divina, que neles nos fala" (CORETH, 1973, p. 3). No contato com os textos canônicos, apócrifos ou profanos extrabíblicos, a práxis exegética exige conhecimento de línguas, do ambiente histórico e cultural, da peculiaridade literária e estilística, da situação concreta e da intenção do autor, bem como do micro e do macrocontextos em que os textos investigados se inserem. Urge superar condicionantes e preconceitos arraigados. Isso será aprofundado pela problemática filosófica, a qual tratará do tema da compreensão "em sua essência e em suas estruturas, suas condições e seus limites" (CORETH, 1973, p. 4), ampliando o campo de reflexão.

Segundo Geffré, uma Teologia com orientação hermenêutica não designa apenas mais uma corrente teológica, mas "o próprio destino da razão teológica no contexto do pensável contemporâneo" (GEFFRÉ, 2004, p. 23), pois diz respeito a uma nova postura diante do pluralismo hodierno, o qual representa um novo paradigma teológico. Diante da atual polifonia religiosa e ideológica entoada pela multiplicidade de culturas e religiões do mundo, com suas consonâncias e dissonâncias, o Cristianismo é chamado a expressar e a redefinir a sua singularidade (GEFFRÉ, 2004, p. 26) e a sua competência comunicativa, seja no âmbito das religiões ou mesmo na esfera pública. A missão profética da Teologia consiste em "atualizar e tornar pertinente para a 
contemporaneidade a mensagem da revelação" (GOMES, 2015, p. 13), para que a mesma se atualize constantemente e se mantenha viva e relevante para as pessoas de hoje, pois, do contrário, isolar-se-ia em um passado cristalizado, inerte e mumificado, não incidindo no presente histórico e social, sem perspectivas esperançosas de edificação de um futuro escatológico na dinâmica do Reinado de Deus.

A teoria teológica enquanto interpretação profética dos fatos salutares almeja ser uma narrativa significativa a partir da revelação (BOFF, 2004, p. 28), a qual tem como ponto de partida a teoria da fé, textualizada e positivada, e a prática da vida concreta e existencial. A Teologia como hermenêutica "procura uma nova inteligência da mensagem cristã” (GEFFRÉ, 1989, p. 69). Para isso, não teme aplicar-se a uma reinterpretação dos enunciados dogmáticos a partir de um melhor conhecimento da situação histórica que foi a ocasião de sua formulação, à luz da leitura atual da Escritura. Uma hermenêutica que foca no mundo do texto ajuda a ultrapassar uma concepção imaginária da revelação (GOMES, 2015, p. 45) e a compreender a Escritura como a tradução dos eventos teofânicos narrados a partir dos testemunhos interpretativos, os quais aproximam e distanciam da faticidade original. "O trabalho do hermeneuta é interpretar uma interpretação" (GEFFRÉ, 2004, p. 48) que remete a uma experiência, que, por sua vez, é interpretante do evento que a suscitou.

É na relação entre a história, os textos de sua origem e tradição, e a realidade atual que é possível entender o papel do Cristianismo na construção de uma verdadeira paz religiosa. Para além disso, no entanto, aparece a demanda a respeito de sua contribuição num mundo marcado pela violência e pela injustiça. Para ir ao encontro dessa questão, propõem-se, a seguir, algumas linhas para estender a paz entre as religiões para a paz mundial.

\section{Cristologia e diálogo entre as religiões em busca da paz}

Deus se revela para salvar, e a história da salvação, para Geffré, não se restringe à economia judaico-cristã̃ . A salvação de Deus não está restrita a uma

\footnotetext{
${ }^{2}$ Para Geffré, há em primeiro lugar uma história geral da salvação, coextensiva à história do mundo, e uma história da revelação como segundo momento que se desenrola desde o primeiro 
religião em particular, sua ação excede os limites visíveis e compreensíveis das instituições culturais e religiosas. "Deus quer a salvação e a felicidade de todos os homens" (GEFFRÉ, 2013, p. 65). Essa salvação é veiculada por meios limitados, os quais são sacramentais de uma graça abundante e misteriosa que não faz distinção de pessoas. A salvação está no mundo para além das religiões, pois estas são instrumentos da graça divina salvadora que penetra o universo e cala fundo no coração humano. Segundo Geffré, "as Igrejas, mas também as religiões, não são, elas mesmas, a salvação, mas o sacramento da salvação, isto é, da presença salvífica, silenciosa, mas atuante, de Deus, que conduz a criação ao seu acabamento pela intermediação das liberdades humanas" (GEFFRÉ, 2013, p. 66). A missão das religiões é ser um instrumento do divino.

\begin{abstract}
Mesmo sendo Jesus Cristo realmente, para a fé cristã, a revelação decisiva e definitiva sobre Deus, não podemos pretender que o Cristianismo tenha o monopólio da verdade religiosa sobre Deus e sobre as relações com Deus. Há, nas outras religiões, experiências religiosas autênticas que não foram, e não serão tematizadas ou postas em prática no interior do Cristianismo pelo fato mesmo de sua particularidade histórica. [...] Deve-se reconhecê-las na sua diferença, em vez de reconhecer nelas valores implicitamente cristãos (GEFFRÉ, 2013, p. 71-72).
\end{abstract}

De acordo com Geffré, a plenitude da revelação de Deus e o próprio acontecimento Jesus Cristo não estão circunscritos exclusivamente à letra do Novo Testamento. Além disso, não basta uma concepção cronológica e linear da história da salvação, que ignore a sua dimensão escatológica. A pluralidade das religiões como manifestação da riqueza multiforme do mistério divino é a expressão do desígnio soteriológico universal de Deus para toda a humanidade. É importante tomar consciência disso prescindindo de todo absolutismo exclusivista, porém, sem cair em um relativismo indiferente. Pode ajudar, nesse sentido, voltar ao centro mesmo da fé cristã, adentrando no mistério da "irrupção de Deus na particularidade histórica de Jesus de Nazaré" (GEFFRÉ, 2013, p. 74), que paradoxalmente identifica em si mesmo a concretude imanente e a universalidade transcendente. A consciência dessa

(GEFFRÉ, 2004, p. 70). Para Hick, por exemplo, todas as religiões, inclusive o Cristianismo, giram em torno do mistério de Deus (HICK, 1980) e para Panikkar, as religiões giram em torno de Cristo (PANIKKAR, 1981). 
realidade limitada que pretende expressar o ilimitado ajuda na percepção de uma misteriosa complementaridade entre as religiões, não no sentido de conceber uma democracia inter-religiosa na qual todas as religiões seriam equivalentes, mas na possibilidade de um encontro dialógico entre as religiões, tendo sempre presente a alteridade irredutível de cada identidade.

\section{O diálogo entre as religiões como pedagogia para a paz}

O Concílio Vaticano II enfrentou a questão da Igreja diante das outras religiões dentro de padrões tradicionais irrenunciáveis, tais como a unicidade de Cristo para a salvação do gênero humano e a mediação sacramental da Igreja. Apesar de uma visão positiva, deixou em aberto o debate teológico (DUPUIS, 1999, p. 251). Atualmente a abundante produção teológica sobre a Teologia das Religiões demonstra a importância que se dá ao tema. Hick defende uma "revolução copernicana" da Cristologia, passando da perspectiva cristocêntrica tradicional para a perspectiva teocêntrica, segundo a qual todas as tradições religiosas, incluindo o Cristianismo, giram em torno de Deus (HICK, 1973; 1977; 1980). Hick propõe o modelo do "centramento sobre a Realidade". Todas as religiões são orientadas de modos diversos para a Realidade Central ou o Absoluto Divino (HICK, 1989). Geffré acolhe alguns elementos do pensamento de Hick, porém, não chega a assumir o pluralismo de forma tão radical a ponto de considerar todas as religiões equivalentes.

Segundo Dupuis, o atual contexto de diálogo serve de questionamento ao testemunho neotestamentário sobre o significado universal de Cristo. Esse testemunho pertence de fato à substância da mensagem revelada ou advém do contexto cultural que veiculou a experiência dos primeiros cristãos? Para Dupuis, a Teologia cristã não se encontra diante do dilema de ser cristocêntrica ou teocêntrica, pois é teocêntrica ao ser cristocêntrica e vice-versa. Em Jesus a ação salvífica de Deus atinge todas as pessoas de vários modos, consciente ou inconscientemente (DUPUIS, 1999, p. 267). Geffré segue mais esse viés de Dupuis, de uma cristologia inclusiva, porém, aberta para a realidade do pluralismo religioso.

D'Costa (1986) relembra dois axiomas fundamentais da fé cristã: a universalidade da vontade salvífica de Deus e a necessidade da mediação de 
Cristo. Enquanto o exclusivismo se baseia no segundo axioma, ignorando o primeiro, e o pluralismo sobre o primeiro em detrimento do segundo, apenas o inclusivismo consegue explicá-los e defendê-los simultaneamente. D'Costa está convicto de que só o inclusivismo pode harmonizar os dois axiomas tradicionais da fé cristã, que são imprescindíveis para qualquer Teologia das Religiões. Revelado de maneira decisiva em Cristo, Deus e o seu mistério de salvação não estão menos presentes e atuantes em outras tradições religiosas. Essa perspectiva mais moderada é compartilhada pelo Magistério da Igreja católica (cf. LG 16-17, NA 2).

Knitter propõe um "Reinocentrismo" ou "soteriocentrismo" o qual defende que todas as religiões, na medida em que contribuem para a libertação das pessoas, são vias de salvação para os seus seguidores. Knitter alerta para o compromisso comum das diferentes tradições religiosas para o bem-estar eco-humano. Deus e o Reinado são a meta da história para a qual todas as religiões, incluindo o Cristianismo, convergem. Esse modelo considera os seguidores de todas as religiões como membros do Reinado de Deus na história e co-peregrinos dirigindo-se à plenitude escatológica de Deus no final dos tempos (KNITTER, 1985).

O pluralismo religioso afunda suas raízes nas profundezas do mistério divino e nas variadas formas como as culturas humanas responderam a ele. $\mathrm{O}$ pluralismo, longe de ser um obstáculo a ser superado, precisa ser acolhido com gratidão como um sinal da superabundante riqueza do mistério divino que transborda sobre a humanidade. Podemos encarar a questão na perspectiva do encontro e do diálogo (DUPUIS, 1999, p. 277-278). Segundo Tracy, é preciso construir uma "Teologia do diálogo", que acontece na assimetria, pela diferença dos participantes (TRACY, 1990). É preciso reconhecer honestamente que comunidades religiosas diferentes propõem de fato objetivos diferentes para a vida humana. Em nenhum momento, uma interpretação deve se tornar exclusiva de outra. Atualmente, há certo consenso em evitar tanto o absolutismo quanto o relativismo. A pluralidade deve ser levada a sério e acolhida positivamente, pois ela tem um lugar próprio no plano de Deus para a salvação da humanidade. A afirmação da própria identidade religiosa não cresce a partir da contraposição violenta com as 
outras (DUPUIS, 1999, p. 281-282), mas ambas podem ser harmonizadas em uma convivência pacífica.

A unidade da família humana deveria ser uma prioridade para aqueles que se dizem filhos de Deus. Brigas e intrigas dilaceram a comunhão na casa comum que é o nosso planeta e é escândalo para os descrentes. Por isso, "o diálogo inter-religioso é uma condição necessária para a paz no mundo" (EG 250). A humanidade precisa aprender a conviver na diversidade, aceitando as diferenças culturais, religiosas e étnicas, a fim de superar os conflitos e edificar a paz. No entanto, não basta estabelecer um sincretismo conciliador e totalitarista (EG 251), é preciso dialogar respeitando as diferenças, na fidelidade à própria identidade, buscando pontos comuns de convergência e conciliação que ampliem os horizontes vitais (GEFFRÉ, 2013, p. 15-18). Um pluralismo saudável respeita aqueles que pensam diferente e defende o direito de que todos tenham a oportunidade de se manifestar publicamente (EG 255).

$\mathrm{Na}$ aurora do século XXI, em cada religião há homens e mulheres que estão dispostos a ultrapassar suas querelas ancestrais, a renunciar à sua vontade de conquista e de dominação para se pôr a serviço do homem. Eis aí um sinal dos tempos. Em Assis, em 1986, as autoridades religiosas mais respeitadas no mundo se encontraram como mensageiros de paz. Em contraste com essa vontade de diálogo, o renascimento de fanatismos e de integrismos assume um caráter escandaloso para o observador do futuro das religiões no mundo (GEFFRÉ, 2013, p. 23).

Nesse sentido, "o diálogo inter-religioso é um sinal de novos tempos, onde é possível reinar a fraternidade no convívio dos diferentes, onde a busca da verdade possa acontecer através da procura sincera e humilde" (GOMES, 2015, p. 82), sem desrespeito à alteridade plural. Mais do que nunca, têm-se a consciência de que "a verdadeira humanidade é o pressuposto para a verdadeira religião" e a "verdadeira religião é a realização da verdadeira humanidade" (KÜNG, 1992, p. 129) e de que, "diante do aumento do fanatismo, do racismo, do terrorismo internacional, dos genocídios por motivo étnico, os valores morais recomendados pelas religiões são mais atuais do que nunca" (GEFFRÉ, 2013, p. 24).

A fim de possibilitar essa convivência pacífica entre as religiões requer-se, conforme Geffré, da parte cristã, a consciência de que são, "por pura graça, as testemunhas da revelação que Ihes foi confiada por Jesus Cristo, 
mas não são seus proprietários" (GEFFRÉ, 2013, p. 61). Ser crente não significa possuir a verdade total sobre Deus, mas, numa posição de aceitação da pluralidade de expressões religiosas no interior do único desígnio divino, respeitar a experiência do outro e sinceramente buscar a verdade. Exige reinterpretar muitas das verdades de fé a respeito da salvação e do conhecimento do mistério de Deus, em humildade diante de um mistério que não pode ser abarcado pelos limites da racionalidade humana. O diálogo tenciona interrogar e desapropriar a fé de todo egocentrismo, provocando-a a aprofundar sua autocompreensão. No diálogo com outras religiões, toda tentativa de dominação alheia se revela soberba e prepotente.

No encontro entre as pessoas de diversas religiões, o respeito às diferenças e a resolução dos conflitos de maneira não violenta 3 é de fundamental importância para a aprendizagem de uma convivência humana saudável. Trata-se de um exercício pedagógico para a construção da paz, o que em termos de Hans Küng e do Parlamento das Religiões é uma condição para a paz entre os povos. Enquanto "uma necessidade concreta para a maioria da população e meta prioritária para os governantes" (MILANI, 2000, p. 51), a paz pode, assim, ser reforçada com uma transformação da violência simbólica, da qual a religião é uma das expressões. O diálogo entre as religiões educa sujeitos críticos, capacitando para promover transformações sociais, a partir do conhecimento dos processos, do cultivo do diálogo, da tolerância e da acolhida entre pessoas e instituições, a fim de redescobrirem e criarem "espaços de afetividade e conhecimento, para a construção efetiva de uma cultura de paz" (MATOS, 2006, p. 174). O diálogo inter-religioso constitui-se, portanto, num exercício cotidiano e permanente de percepção de interdependência de todo ser humano, na escuta do outro, na construção de um relacionamento gentil com o diferente, na aprendizagem para lidar com os conflitos, para criar um ambiente acolhedor e humanizado. Viver em paz é um aprendizado que exige criatividade e flexibilidade operante, relativizando a

\footnotetext{
${ }^{3}$ Para Gandhi, a não violência traduz os termos sânscritos ahimsa ( $a=$ não + himsa $=$ violência) e satyagraha (saty = verdade + agraha = firmeza) com os quais Gandhi descrevia o método de resistência e transformação social na África do Sul e na Índia (GANDHI et al., 2007, p. 552-558).
} 
posse particular da verdade em vista de uma interpretação nova das próprias tradições.

\section{Do diálogo entre as religiões à Teologia da Paz}

Para além do diálogo inter-religioso como exercício para a convivência pacífica, a Teologia e a Cristologia têm um desafio ainda maior: o de se transformarem para ajudarem na superação da violência e na construção de uma sociedade pacífica. Especialmente, a partir da realidade brasileira, é necessário elaborar conceitos adequados a favor de uma sociedade em que a justiça social e a superação da violência estrutural acompanhem o ideal da paz. Não há quem não se sinta tocado de alguma maneira pela violência que extermina a vida em suas mais variadas maneiras, impondo-se o empenho "sobre a urgência de redefinição dos próprios padrões de relação e de valores na busca de uma convivência pacífica” (cf. HAMMES; BOLDORI, 2013, p. 103108, aqui, p. 106). Redescobrir a presença do “Deus de amor e de paz" (2 Cor 13,11), que compartilha a dor e o sofrimento das vítimas da injustiça e da violência e que promete a paz à humanidade, pode ajudar a perceber a paz como dom divino e tarefa humana, que exige fé teologal e atitude ética.

A paz de que aqui se fala não consiste na supressão, mas na transformação dos conflitos. A conflitividade enquanto exprime colisão de objetivos entre sujeitos faz parte da vida. É parte da dinâmica de toda realidade. O que não é natural e nem determinado é a forma de resolver a conflitividade: de maneira violenta ou não violenta. E por violência aqui se pode operativamente referir a destruição da vida. A não violência se traduz sempre no esforço de preservar a vida, a existência do outro ser e do ser do outro, da outra. Trata-se de uma forma cultural de enfrentamento dos conflitos. A violência, portanto, é uma questão cultural e pode ser superada pela não violência e a paz. Essa é a conclusão de diferentes autores dedicados às pesquisas de paz, mesmo discordando quanto ao papel das religiões. A realidade como tal vive de conflitividade e de equilíbrio entre polaridades. $A$ questão é sempre a resolução não violenta e criativa dos conflitos (GALTUNG, 1996, p. 9) para evitar situações de guerra e buscar a paz. 
Em termos de relações entre os povos, a realidade da perpétua alternância de processos de guerra e paz (OLIVEIRA, 2004, p. 41-42) hoje chegou ao seu limite. A guerra é uma ameaça real à sobrevivência da espécie, mas é também um absurdo ético diante dos recursos disponíveis à resolução pacífica dos conflitos. O arsenal mortífero disponível às potências nucleares desde a segunda guerra mundial não permite mais aventar a hipótese de uma guerra, sob pena de ser o final da civilização humana. Mais fundamentalmente, no entanto, qualquer guerra, mesmo com armas convencionais, já não pode ser considerada um caminho de superação de conflitos. Mesmo os argumentos tradicionais em favor da guerra justa são inaceitáveis porque impraticáveis: a população civil desde há muito não pode ser protegida e suas perdas são consideradas parte dos efeitos colaterais.

Em certo sentido, a polarização freudiana entre éros e thánatos, entre amor e ódio mortífero, em que "a vida, em última instância, depende de forças capazes de resistirem aos impulsos de morte e assassinato" (cf. HAMMES, 2015, p. 67-68), precisa ser superada por uma nova forma de relacionamento, potencializando a capacidade de diálogo. O instinto de autopreservação em um contexto competitivo muitas vezes exacerbado em comportamento homicida reclama uma atitude necessária de heteropreservação, na qual o amor neutraliza a tendência tanatológica.

A insistência num conceito positivo de paz aplica-se também para a paz social especialmente como parte das relações internas das nações. Como testemunho do estágio da reflexão atual, podem mencionar-se as indicações do Papa Francisco na Exortação Apostólica Evangelii Gaudium. Segundo o texto, a paz "não pode ser entendida como irenismo ou como mera ausência de violência” (EG 218). Para além de uma Teologia negativa, é imprescindível construir uma Teologia propositiva e cheia de esperança, articulada pela colaboração das religiões em prol de um mundo mais humano e mais divino, onde reine a paz. É necessário profetizar contra a "tranquilidade de alguns que não querem renunciar aos seus privilégios" (EG 218) e que por isso ferem a dignidade humana e o direito dos povos. Trata-se de priorizar "ações que geram novos dinamismos na sociedade" (EG 223), sem imediatismo, mas com paciência histórica, clareza de ideias e convicções fortes. "O conflito não pode ser ignorado ou dissimulado; deve ser aceito. Mas, se ficamos encurralados 
nele, perdemos a perspectiva, os horizontes reduzem-se e a própria realidade fica fragmentada" (EG 226). Parar no conflito significa perder o sentido da totalidade do real; ficar alheio a ele corresponde a cair na indiferença. Ambos, desespero e indiferença não ajudam a buscar a reconciliação e a paz. É mais adequado, nesse sentido, "aceitar suportar o conflito, resolvê-lo e transformá-lo no elo de um novo processo" (EG 227). A paz enquanto harmonização das diferenças e riqueza de uma diversidade reconciliada (EG 230) deve ser a síntese que prevalece nos conflitos.

A partir da América Latina, pode associar-se o conceito de paz com o mistério de libertação vislumbrado no rosto de Jesus em contraposição ao mistério de iniquidade, representado nas vítimas da violência (SOBRINO, 1994, p. 16). A memória jesuânica rompe o torpor diante de uma realidade interpeladora. Propor uma hermenêutica não violenta em vista de um diálogo entre as religiões em busca da paz partindo do próprio fundamento cristológico da revelação significa propiciar novas perspectivas para uma resolução criativa e não violenta dos conflitos enfrentados cotidianamente entre as religiões e na própria sociedade. Jesus anunciou e proclamou um Deus de amor e de paz, chamando as pessoas a se converterem dos erros e da violência e crerem no Evangelho da vida, que é Boa Nova transformadora da realidade. Somente o amor abnegado e incondicional supera a violência, não produzindo mais vítimas. É na dinâmica do amor que Jesus conquista a paz escatológica para a humanidade, "parece abrir veredas e conferir um caminho da paz para a humanidade" (HAMMES; BOLDORI, 2013, p. 106) que não se corrompe em sua integridade e nem se deixa vencer pela violência. A cruz, como consequência da existência resistente de Jesus à violência, é sinal do amor pacificador divino que não paga a violência com a violência, antes a atravessa e anula.

A paz, finalmente, abrange toda a realidade. $\mathrm{Na}$ expressão da Carta da Terra (n. 16, letra f) a paz "é a plenitude criada por relações corretas consigo mesmo, com outras pessoas, outras culturas, outras vidas, com a Terra e com a totalidade maior da qual somos parte." As questões sociais, as relações interpessoais e internacionais, mesmo, implicitamente, a relação ao Transcendente são parte integrante da construção da paz. E do ponto de vista cristão e religioso, para além das relações interconfessionais e inter-religiosas, 
requer-se o engajamento em favor da justiça e da superação dos conflitos, para compreender e assumir a realidade numa espiritualidade da paz e não violência que se nutre "da solidariedade com as vítimas da violência, sejam amigas ou inimigas, nacionais ou estrangeiras" (HAMMES, 2015, p. 70), conforme o mandamento do amor (Mt 22,36-39; MC 12,28-31; LC 10,25-28).

\section{Considerações finais}

A Teologia de Geffré representa uma tentativa de resposta a duas situações aqui abordadas: o pluralismo e conflitividade religiosa e a realidade da violência social. Historicamente houve duas soluções extremas mutuamente excludentes na Teologia das Religiões: o exclusivismo e o pluralismo radical. Uma terceira posição, o inclusivismo, em alguma de suas vertentes, acabava por anular a grandeza própria do universo religioso plural.

O caminho da solução proposta pelo autor aqui estudado inicia com a aplicação do princípio interpretativo - hermenêutica — à fé cristã. Demonstra-se desse modo a plasticidade do Cristianismo em sua estrutura profunda. Toda expressão de fé, por ser condicionada pelo seu tempo e espaço, precisa dialogar com as novas condições da realidade na qual se insere. É o que o autor chama de dimensão quenótica do Cristianismo. Representa sua qualidade de poder entrar em qualquer situação, despojando-se das formas anteriores para, em certo sentido, se tornar outro. Não há uma forma rígida e fixa a ser transferida de um tempo ou lugar a outro, mas existe um princípio, um texto, que pode aprender e compreender sempre novas condições e dizer-se em realidades diferentes da sua, originária. Esse primeiro princípio permite que haja um pluralismo teológico e uma possível pluralidade expressiva da própria fé.

O segundo princípio aplicado por Geffré é o da centralidade crística. Jesus de Nazaré é aceito por muitos como sendo o Cristo, a promessa e a realização da unidade humano-divina. Segundo interpretações reducionistas, Jesus de Nazaré teria esgotado as possibilidades de relação à transcendência em sua história e herança a ponto de excluir outras mediações. Na outra extremidade poderia falar-se de reducionismo minimalista, no sentido de 
considerar a mediação de Jesus de Nazaré como sendo apenas uma entre muitas outras atuais ou possíveis. Na compreensão de Geffré, Jesus de Nazaré realiza como economia do Verbo, de forma quenótica, a mediação, sem esgotar em si todas as possibilidades, mas potencializando, no Espírito Santo, outras formas de mediação. Talvez se pudesse traduzir essa posição como um princípio soteriológico, segundo o qual toda forma de mediação entra na mediação realizada em Jesus de Nazaré por uma espécie de "adoção", sem que seja anulada. Na realidade, esse é o princípio segundo o qual o judaísmo tem uma validação própria, como Aliança permanente, de modo tal que as seguidoras e seguidores do judaísmo não precisam seguir Jesus de Nazaré para estarem na Aliança dele. Visto desse modo, o pluralismo, como fato, não pode servir de pretexto a conflitos entre as religiões, mas é manifestação da pluralidade comunicativa divina e um chamado à construção conjunta e pacífica da sociedade humana.

Finalmente, embora necessária, a paz entre as religiões não é condição suficiente; é, sim, parte do empenho geral do Cristianismo em favor da paz, segundo seu Fundador. E essa paz consiste na transformação criativa e não violenta dos conflitos, em base à prática, ao destino e à interpretação do próprio Jesus Cristo. Se por um lado, historicamente, o Cristianismo passou de grupo minoritário e pacifista no Império Romano à hegemonia e dominação, muitas vezes violenta, as condições atuais do mundo e uma releitura hermenêutica da tradição cristã não deixam dúvida quanto à sua vocação pacífica. O que vale em termos internacionais e nas relações entre os povos aplica-se com mais razão no contexto brasileiro de violência social e política. O respeito, o reconhecimento, a busca da convivência entre as diferentes tradições religiosas, marcadamente indígenas e afro-brasileiras, é parte de uma compreensão atual da tradição cristã e suas confissões. Uma atenção especial, nesse sentido, merecem as posições agnósticas, ateias e laicas. Do ponto de vista cristão, e no caso da Igreja Católica, desde o Concílio Vaticano II, gozam dos mesmos direitos de reconhecimento e respeito como todas as posições religiosas. Dessa atitude, de convivência e busca pacífica de sentido e vida, espera-se uma formação, uma espiritualidade, uma educação e uma prática de paz em sua integralidade, como relação com outras pessoas, com a natureza e com o Totalmente Outro. 
Desse modo, a sociedade atual carente de compaixão e de atitudes solidárias que superem a lógica estrutural e sistêmica da violência e favoreçam novas formas de convivência humana pode encontrar no diálogo entre as religiões uma contribuição para a educação em favor da paz para o bem da humanidade e do planeta. Do ponto de vista cristológico, a releitura dos evangelhos com a perspectiva de uma solução não violenta dos conflitos e a contribuição positiva do amor aos inimigos, da atenção aos pobres, doentes, refugiados e migrantes se torna princípio instaurador de justiça para uma sociedade mais humana e reconciliada.

\section{Referências}

BAUMAN, Z. Tempos líquidos. Rio de Janeiro: Zahar, 2007.

BÍBLIA. Português. A Bíblia de Jerusalém. Nova edição rev. e ampl. São Paulo: Paulus, 2002.

BOFF, C. Teoria do método teológico: versão didática. 5. ed. Petrópolis: Vozes, 2004.

CARTA da Terra. Haia, 2000. Disponível em: <http://www.cartadaterrabrasil.org/prt/text. html>. Acesso em: 02 de Jan. de 2017.

CORETH, E. Questões fundamentais de hermenêutica. São Paulo: EPU, 1973.

CONCÍLIO ECUMÊNICO VATICANO II. Lumen Gentium. In: COSTA, L. (Org. Geral). Documentos do Concílio Ecumênico Vaticano II (1962-1965). 4. ed. São Paulo: Paulus, 2007, p. 101-197.

CONCÍlIO ECUMÊNICO VATICANO II. Nostra Aetate. In: COSTA, L. (Org. Geral). Documentos do Concílio Ecumênico Vaticano II (1962-1965). 4. ed. São Paulo: Paulus, 2007. p. 339-346.

D'COSTA, G. Theology of Religious Pluralism: The Challenge of Other Religions. Oxford: Basil Blackwell, 1986.

DUPUIS, J. Rumo a uma teologia cristã do pluralismo religioso. São Paulo: Paulinas, 1999.

FRANCISCO. Exortação Apostólica Evangelii Gaudium: sobre o anúncio do Evangelho no mundo atual. São Paulo: Paulinas, 2013

FRANCISCO. Carta Encíclica Laudato Si': sobre o cuidado da casa comum. São Paulo: Paulus; Loyola, 2015.

GALTUNG, J. Peace by peaceful means. London; New York; New Deli: Sage, 1996. 
GANDHI, M. et al. Gandhi on nonviolence. New York: New Directions, 2007.

GEFFRÉ, C. Como fazer teologia hoje: hermenêutica teológica. São Paulo: Paulinas, 1989.

GEFFRÉ, C. Crer e interpretar: a virada hermenêutica da teologia. Petrópolis: Vozes, 2004.

GEFFRÉ, C. De Babel a Pentecostes: ensaios de teologia inter-religiosa. São Paulo: Paulus, 2013.

GIBELLINI, R. A teologia do século XX. 2. ed. São Paulo: Loyola, 2002.

GOMES, T. F. A teologia hermenêutica de Claude Geffré e a sua relevância para a teologia da revelação. 2015. 140 f. Dissertação (Mestrado em Teologia) - Faculdade de Teologia, Pontifícia Universidade Católica do Rio Grande do Sul, Porto Alegre, 2015.

HAMMES, E. J. Mística e espiritualidade da paz e não violência. Pistis e Práxis, Curitiba, v. 7, n. 1, p. 65-82, jan./abr. 2015.

HAMMES, E. J.; BOLDORI, M. Cristologia: um caminho para a paz. Anais do Congresso Estadual de Teologia. São Leopoldo: Est, 2013.

HICK, J. An Interpretation of Religion: human responses to the transcendent. New Haven: Yale University Press, 1989.

HICK, J. God and the Universe of Faiths: Essays in the Philosophy of Religion. London: Macmillan, 1973.

HICK, J. God Has Many Names: Britain's New Religions Pluralism. London: Macmillan, 1980.

HICK, J. The Centre of Christianity. London: SCM Press, 1977.

KNITTER, P. No Other Name? A Critical Survey of Christian Attitudes towards the World Religions. Maryknoll New York: Orbis Books, 1985.

KÜNG, H. Projeto de ética mundial: uma moral ecumênica em vista da sobrevivência humana. São Paulo: Paulinas, 1992.

KÜNG, H. Religiões do mundo: em busca dos pontos comuns. Campinas: Verus, 2004.

LIBANIO, J. B. Concílio Vaticano Il: em busca de uma primeira compreensão. São Paulo: Loyola, 2005.

LEXICON. Dicionário teológico enciclopédico. São Paulo: Loyola, 2003.

MAGALHÃES, A. C. Narrativa e hermenêutica teológica. Caminhando, São Paulo, v. 7, n. 1, p. 6-22, 2009. 
MATOS, K. S. L. Juventude, paz e espiritualidade: opção por uma prática educativa ético-amorosa. In: IBIAPINA, I.; CARVALHO, M. V. (Orgs.). A pesquisa como mediação de práticas socioeducativas: IV Encontro de Pesquisa em Educação UFPI. Teresina: EDUFPI, 2006. v. 1, p.167-177.

MILANI, F. Cidadania: construir a paz ou aceitar a violência? In: FREITAS, M. Cidadania mundial, a base da paz. Mogi Mirim: Planeta Paz, 2000.

OLIVEIRA, N. Ética, guerra e paz. In: PIVATTO, P. S. (Org.). Ética: crise e perspectivas. Porto Alegre: Edipucrs, 2004. p. 41-60.

PANIKKAR, R. The unknown Christ of hinduism. Maryknoll: Orbis Books, 1981.

SOBRINO, J. Jesus, o libertador. Petrópolis: Vozes, 1994.

TEIXEIRA, F. A teologia do pluralismo religioso em Claude Geffré. Numen, Juiz de Fora, v. 1, n. 1, p. 45-83, jan./jul. 1998.

TEIXEIRA, F. Teologia das religiões: uma visão panorâmica. São Paulo: Paulinas, 1995. TORRES QUEIRUGA, A. O diálogo das religiões. São Paulo: Paulus, 1997.

TRACY, D. Dialogue with the Other: The Interreligious Dialogue. Louvain: Peeters Press, 1990. 